The Role of Leadership and Motivation of School Headmaster in Improving Teacher Performance

\title{
THE ROLE OF LEADERSHIP AND MOTIVATION OF SCHOOL HEADMASTER IN IMPROVING TEACHER PERFORMANCE
}

\author{
Ahmad Sukandar \\ Program Studi Komunikasi Penyiaran Islam (KPI) \\ Fakultas Agama Islam Universitas Islam Nusantara (UNINUS) Bandung \\ ahmadsukandar@uninus.ac.id
}

\begin{abstract}
This article discusses about role of leadership and motivation of school headmaster in improving teacher performance. By using literature review in education, this article found that teacher is a professional profession where he is required to make every effort to carry out his activities as best he can. The task of the teacher as an educator, teacher and trainer should be able to impact the students. The teacher as one component in teaching and learning activities, has a position that greatly determines the success of learning. The role of the school headmaster is very important and dominant in improving teacher performance, both in increasing competence and work motivation and in building effective work systems and creating a harmonious, safe and pleasant working atmosphere. The efforts of improving the quality of teachers must be continuously carried out by school headmaster in order to improve the performance of teachers into reliable individuals who will advance the school organization. Therefore, we need the ability of the leadership role and motivation of the principal to explore, disseminate, foster and develop the potential of the teacher in order to improve teacher performance in order to achieve educational goals
\end{abstract}

Keywords: leadership; motivation; school headmaster; teacher performance

\section{A. INTRODUCTION}

School management applies the concept of organizational management through the application of policies and rules of conduct in carrying out the school's vision and mission in order to achieve organizational goals (Visscher, 2013, p. vi). The Rules of Procedure are created to create an atmosphere that supports the educational process so that students are motivated in learning and teaching. With the existence of these policies and rules the school must install good teacher teaching performance for all components in it to achieve school management goals to the fullest (Cañado, 2012, p. 128).

One of the keys to the success of school management is the implementation of good teacher teaching performance. Even for the school with the high and orderly teaching performance of the teacher must be an image for the school itself especially for students and their teachers (Hunter, Brown, \& Donahoo, 2012, p. 37). The views of the community and the school on the image with the teaching performance of good teachers will bring positive feedback on the development of the school especially in order to maintain school management. Achieving the management goals of the principal is influenced by one of the good managerial skills of the principal in carrying out all activities in the school (Jones, Jenkin, \& Lord, 2006, p. 5). 
Teachers are one component of education that plays an important role in the success of education. They are expected to be able to play the role of ideal teachers. One way to improve the quality of education is to improve teacher performance (DeVitis \& Irwin-DeVitis, 2010, p. 379). Teacher performance is the teacher's perception of teacher's work performance related to the quality of work (Wragg, Haynes, \& Chamberlin, 2012, p. 29), responsibility (Millman \& Darling-Hammond, 1991, p. 40), honesty (Hoy \& DiPaola, 2009, p. 268), cooperation and initiative (Cheng, 2013, p. 59).

The main task of the teacher is to educate, teach, guide, direct, train, assess, and evaluate students in early childhood education in formal education, basic education, and secondary education (Gravells, 2017, pp. 32-68) as well as additional tasks relevant to the function of the school. The teacher is a professional profession where he is required to make every effort to carry out his activities as best he can. The task of the teacher as an educator, teacher and trainer should be able to impact the students. The teacher as one component in teaching and learning activities, has a position that greatly determines the success of learning (UNICEF, 2009, p. 2). Because the teacher's main function is designing, managing, implementing and evaluating learning. The existence of teachers in the world of education is very crucial, because the obligation is not only to transform knowledge but also required to internalize values in students. The form of values internalized at least includes ethical, pragmatic, sensory and religious effects (Robertson, Corbin, Tranter, \& Bartlett, 2010, p. 59).

In addition, the position of the teacher in teaching and learning activities is also very strategic and decisive. It is strategic because the teacher will determine the depth and breadth of the subject matter, while it is decisive because the teacher chooses and sorts the learning material that will be presented to the students (Douglas \& Stirling, 2015, p. 2019). One of the factors that influence the success of the teacher's task is its performance in planning / designing, implementing and evaluating the teaching and learning process. The teacher's performance has a relationship with the behaviour of the teacher in carrying out the task, often found conditions that lead to indications of low performance that will have an impact on low school performance (Shepherd \& Linn, 2014, p. 25).

Improving the quality of learning and the professionalism of teachers in their performance is closely related to the effectiveness of the role of the principal. In an organization that is dynamic and flexible about changes such as education, principals play a very important role in helping teachers improve their performance (Robertson et al., 2010, p. 25). The skills and wisdom of the principal's leadership is one of the professional education leaders in the school organization whose task is to manage all organizational resources and work with teachers in achieving educational goals. The principal is one component of education that has an effect on improving teacher performance (Odden, 2009, p. 131).

The head school is responsible for organizing educational activities, school administration, fostering other education staff, and utilizing and maintaining facilities and infrastructure. This becomes more important in line with the increasingly complex demands of the principal's job, which requires more effective and efficient performance support. The principal is a figure who is able to become a facilitator to achieve educational goals because in a bureaucratic hierarchy the principal is an extension of the government to realize the ideals and goals of education (Simmons \& Hawkins, 2009, p. 217).

The other principal is a vital element for the effectiveness of educational institutions. A good headmaster will be dynamic to prepare various kinds of educational programs. School successes and failures are largely determined by the school principal, because the school headmaster controls and determines the direction the school intends to pursue and the educational goals. The successful 
headmaster is when he understands the existence of the school as a complex organization, and is able to carry out the roles and responsibilities to lead the school (Skager, 2014, p. 80). Therefore, we need the ability of the leadership role and motivation of the principal to explore, disseminate, foster and develop the potential of the teacher in order to improve teacher performance in order to achieve educational goals

\section{B. METHOD}

This article deals with the field of education, so the writing method used is an educational research method, namely as a scientific way to obtain valid data with the aim of being able to be found, developed, and proven, certain knowledge so that it can be used to understand, solve, and anticipating problems in the field of education (Newby, 2013). The study of documents is collecting data by digging documents that have relevance to the objectives of the study, such as the theory and leadership concept data that the principal must have, the task guide and the principal's performance, these documents will be logical and rational evidence to strengthen the argument and facts (Lankshear, 2004).

\section{RESULT AND DISCUSSION}

\section{The Role of School Headmaster Leadership}

Leadership is an important dynamic force in motivating and coordinating organizations in order to achieve goals through a process to influence others (Akram, Lei, \& Haider, 2016), both within the organization and outside the organization to achieve desired goals in a particular situation and condition. The leader is essentially someone who influences the behaviour of others in his work by using power. Power is the ability to direct and influence subordinates in relation to the tasks that must be carried out (Grace, 2005, p. 10).

The school headmaster as leaders in schools certainly influence other people (Hilton, Hilton, Dole, \& Goos, 2015) such as teachers and other education personnel to achieve the goals set by the school. The goal will be achieved if the principal is willing and able to build commitment and work hard to make the school he leads into a quality school that is the best in his area (Macdonald, Dixon, \& Tiplady, 2019, p. 6). In the theory of leadership there are at least two leadership styles, namely task-oriented leadership and human-oriented leadership (Remington, 2016, p. 51). In order to improve teacher competency, a principal can apply both leadership styles appropriately and flexibly, adapted to existing conditions and needs.

The school headmaster is said to be an effective leader if he is able to carry out his role to encourage, influence, direct the activities and behaviour of his group. The Headmaster of School is very instrumental in developing education staff (Mosiori \& Thinguri, 2015). This is the direction the organization intends to go towards the goal must be such that it optimizes the use of all available facilities and infrastructure (Palanithurai, 2011, p. 42).

The most suitable alternative leadership model applied in schools is learning leadership (Edwards, Elliott, Iszatt-White, \& Schedlitzki, 2013) because the school's primary mission is to educate all students and provide opportunities for them to gain the knowledge, skills, and values needed to become successful adults in facing the future unknown and which is loaded with very turbulent challenges. This mission then requires schools as organizations (Parsons \& Taylor, 2011) to focus on learning focused schools, which include curriculum, teaching and learning processes, and assessment of learning outcomes (assessment). 
The definitions of effective learning leadership according to Daryanto (Daryanto, 2011, p. 86) and made clearer by Herawan (Herawan, 2017) belong to the headmaster school are: (1) socializes and implements the contents and meaning of the school's vision well. He was also able to establish habits of sharing opinions or discussing in formulating the vision and mission of his school, and he also always maintained that the school's vision and mission agreed upon by the school community thrived in its implementation; (2) involves stakeholders in school management (participatory management), in the form of involving stakeholders in decision making and in school operational activities in accordance with the capabilities and applicable jurisdiction limits; (3) provides support for learning, for example he supports that teaching that focuses on students' learning interests must be a priority; (4) monitors the teaching and learning process so that he understands more deeply and is aware of what is happening at school; (5) acts as a facilitator so that in various ways he can find out about learning difficulties and can help teachers overcome these learning difficulties.

In its implementation, the success of the principal's leadership is, according to Burhanudin, strongly influenced by the following (Burhanudin, 1994, p. 81) and (Kristiawan, Safitri, \& Lestari, 2017, p. 15): (1) Strong personality. The principal must develop his personality so that he is confident, brave, passionate, generous, and has social sensitivity; (2) Understand education goals well. Good understanding is the main provision of the principal to be able to explain to the teacher, staff and other parties and find the right strategy to achieve it; (3) Extensive knowledge. The school principal must have extensive experience and knowledge of his field of work and other related fields; and (4) Professional skills related to his duties as headmaster, namely technical skills such as preparing lesson schedules and leading meetings; human relations skills such as working with others, motivating teachers /staff; and conceptual skills, such as estimating problems that arise and finding solutions.

If a School Headmaster fulfils all the requirements above, then the educational goals will be achieved as planned. Therefore, a principal / madrasa as a leader / leader must be able to understand, explore, and apply several concepts of management science.

\section{Role of School Headmaster in Motivating Teacher Performance}

The school headmaster is a driver for doing certain actions in achieving education goals. Motivation is a desire that exists in someone who stimulates to take action. The task of the School Headmaster as a motivator includes three things (Manan, 2014), namely the ability to regulate the work environment (Moore, 2012), to regulate the work atmosphere (Dongjiao, 2015, p. 7) to set the principle of reward and punishment (Langa, 2014) including being able to develop external and internal motivation for all of school activities (Khan \& Iqbal, 2014).

Motivation is the process of influencing or encouraging from the outside of a person or work group so that they want to implement something that has been determined (Buble, Juras, \& Matić, 2014). As a Motivator the school headmaster must have the right strategy to provide motivation to the education staff as well as to the students. For students, motivation can be divided into two types, namely intrinsic and extrinsic motivation (Sansone \& Harackiewicz, 2000). Intrinsic motivation in learning is all the encouragement that comes from within the students themselves that can encourage them in learning. Extrinsic motivation is all the encouragement that comes from outside the student who can encourage him to learn subjects in school. As a motivator, the principal's job is to strive so that students' learning motivation can continue to be stable or even improved (Oletić \& llić, 2014). 
According to the observations the authors found that from the two types of motivation above, intrinsic motivation has a large role in improving student learning outcomes, as well as improving teacher performance. The school headmaster should make efforts to be able to arouse students' enthusiasm in learning, and improve teacher performance (Kadir \& Pashiardis, 2014, p. 397). The process of utilizing all school resources carried out through rational and systematic actions to increase motivation especially towards improving teacher performance is part of the performance of the school principal as a motivator (Capone, D’Acunto, Sorbo, Regno, \& Tortoriello, 2016).

If the School Headmaster's role is maximized as a motivator for teacher performance, of course it is in line with the concepts and theories put forward by Kartini Kartono (Kartono, 1998, p. 70) who explain that, the principal's task as a motivator includes three things namely the ability to regulate the work environment, such as regulating things that are mentioned above.

The School Headmaster can apply the school principals to encourage education staff to be willing and able to improve their professionalism(Secretariat, 2002, p. 189) include: (1) educational staff will work harder if the activities carried out are interesting and fun; (2) the purpose of the activity needs to be clearly arranged and informed to the education staff and education staff involved in the preparation of these objectives; (3) educational staff must always be informed of the results of each work; (4) giving a gift is better than punishment, but at any time punishment is also needed; and (5) try to meet the needs of the teaching staff by paying attention to their physical condition, providing a sense of security, showing that the headmaster of the madrasa takes care of them, organizing experiences in such a way that each employee has received satisfaction and appreciation Kartono (Kartono, 1998, p. 70).

Thus, a School Headmaster in his function as a motivator must be able to strive so that the teacher and all educational staff (Wendel, Hoke, \& Joekel, 1996, p. 78). The scope of motivation is spread in the relevant aspects and always improve the abilities and responsibilities of the people. Th reward can be raised by paying attention to welfare, and a sense of togetherness to achieve work productivity that is in accordance with the intended goals (Potter \& Brittain, 2009, p. 83).

Teachers need motivations that come from outside themselves (Leithwood \& Beatty, 2007, p. 85), which of course really needs to be considered by managers or principals. However, motivation begins within the teacher himself. Self-impulse will be more successful than outside encouragement. When the motivation divided into two types: (1) Intrinsic motivation is motivation that arises from within a person (Marquis \& Huston, 2009, p. 422). This motivation is often called "pure motivation" (Grant, 2014 , p. 114); for example, the need for achievement, the need for feelings of acceptance. In another statement, intrinsic motivation is motivation that comes from feeling satisfied in carrying out one's own work. It is a direct part of the work content. Therefore, intrinsic motivation comes from within the individual; and (2) extrinsic motivation is motivation that comes from outside oneself. For example, promotion, praise, gifts and so on (Franklin, 2014, p. 221).

So, from the description above, it can be stated that what is meant by the work motivation of School Headmaster is to direct, and encourage a teacher to take action and overcome all challenges and obstacles in an effort to achieve educational goals. Thus, as a dimension of the form that is considered the most efficient way to support teacher performance is through the supervision of the principal and the motivation of the principal. With this motivation that teachers have enthusiasm both from within themselves and from the encouragement of others to express their potential; that is the energy is released and used depends on the strength of work motivation, situations and opportunities available. 
The energy will be utilized by the teacher because it is driven by three dimensions and indicators of work motivation developed and proposed by Hasibuan (Hasibuan, 2005, pp. 149-167) as follows: (1) Motives: (a) fair wages; (b) opportunities for advancement or promotion; (c) recognition as an individual; (d) work security; (e) a comfortable workplace; (f) acceptance by groups; (g) reasonable treatment; and (h) recognition of achievements; (2) Expectations: (a) good working conditions; (b) feelings of being involved; (c) wise discipline; (d) full appreciation for the completion of work; (e) leadership loyalty to teachers; and (f) sympathetic understanding of personal issues; and (3) Incentives: (a) intrinsic in the form of completion and achievements; and (b) extrinsic in the form of financial (salary and wages, benefits), interpersonal and promotion.

\section{CONCLUSIONS}

The motivation given by the principal has a significant influence on improving teacher performance. Based on the explanation above, explaining that the role of the principal in providing motivation for improving teacher performance is very necessary, it is evidenced that the motivation of principals plays an important role in improving teacher performance even described in the results of the distributed questionnaires in the category of high influence. So, the results of this study at the same time support and strengthen the concepts and theories which explain that the task of the principal as a motivator includes three things, namely the ability to regulate the work environment, such as managing the principal's office space, administrative space, classrooms, laboratories, Guidance and Counselling, Intra-School Student Organizations, libraries, School Health Units, and so on; the ability to regulate the work atmosphere, such as creating harmonious working relationships between teachers / staff / employees, and being able to create a sense of security in school; and the ability to establish principles of appreciation and punishment (reward and punishment) including being able to develop external and internal motivation for everyone in the school.

\section{REFERENCES}

Akram, T., Lei, S., \& Haider, M. J. (2016). The impact of relational leadership on employee innovative work behavior in IT industry of China. Arab Economic and Business Journal, 11(2), 153161. https://doi.org/10.1016/j.aebj.2016.06.001

Buble, M., Juras, A., \& Matić, I. (2014). THE RELATIONSHIP BETWEEN MANAGERS' LEADERSHIP STYLES AND MOTIVATION. Journal of Contemporary Management Issues, 19(1), 161-193.

Burhanudin. (1994). Analisis Administrasi Manajemen dan Kepemimpinan Pendidikan. Jakarta: Bumi Aksara.

Cañado, M. L. P. (2012). Competency-based Language Teaching in Higher Education. New York London: Springer Science \& Business Media.

Capone, R., D’Acunto, I., Sorbo, M. R. D., Regno, F. D., \& Tortoriello, F. S. (2016). Action Research: A New Perspective in Math and Science Education. Conference Proceeding New Perspectives In Scienze Education, 526-530. Retrieved from https://ardhindie.com/book/read.php?file=conference-proceeding-new-perspectives-inscienze-education

Cheng, Y. C. (2013). School Effectiveness And School-Based Management: A Mechanism For Development. New York - London: Routledge. 
Daryanto. (2011). Peran Kepala Sekolah sebagai Pemimpin Pembelajaran. Yogyakarta: Gaya Media.

DeVitis, J. L., \& Irwin-DeVitis, L. (2010). Adolescent Education: A Reader. Washington DC: Peter Lang.

Dongjiao, Z. (2015). School Culture Improvement. Delft: River Publishers.

Douglas, S., \& Stirling, L. (2015). Children's Play, Pretense, and Story: Studies in Culture, Context, and Autism Spectrum Disorder. New York - London: Routledge.

Edwards, G., Elliott, C., Iszatt-White, M., \& Schedlitzki, D. (2013). Critical and alternative approaches to leadership learning and development. Management Learning, 44(1), 3-10. https://doi.org/10.1177/1350507612473929

Franklin, M. (2014). Agile Change Management: A Practical Framework for Successful Change Planning and Implementation. London - Philadelphia -New Delhi: Kogan Page Publishers.

Grace, G. (2005). School Leadership: Beyond Education Management. London - New York: Routledge.

Grant, R. W. (2014). Strings Attached: Untangling the Ethics of Incentives. New York: Princeton University Press.

Gravells, A. (2017). Principles and Practices of Teaching and Training: A Guide for Teachers and Trainers in the FE and Skills Sector. London: Learning Matters.

Hasibuan, M. S. P. (2005). Manajemen Sumber Daya Manusia. Jakarta: Bumi Aksara.

Herawan, E. (2017). Kinerja Kepala Sekolah Sebagai Instructional Leader. Pedagogia, 13(3), 167172. https://doi.org/10.17509/pedagogia.v13i3.6002

Hilton, A., Hilton, G., Dole, S., \& Goos, M. (2015). School Leaders as Participants in Teachers' Professional Development: The Impact on Teachers' and School Leaders' Professional Growth. Australian Journal of Teacher Education, 40(12).

Hoy, W. K., \& DiPaola, M. (2009). Studies in School Improvement. www.infoagepub.com: IAP.

Hunter, R. C., Brown, F., \& Donahoo, S. (2012). School Governance. Washington DC: SAGE Publications.

Jones, J., Jenkin, M., \& Lord, S. (2006). Developing Effective Teacher Performance. Washington DC: SAGE.

Kadir, B., \& Pashiardis, P. (2014). Multidimensional Perspectives on Principal Leadership Effectiveness. Hershey: IGI Global.

Kartono, K. (1998). Pemimpin dan Kepemimpinan. Jakarta: RajaGrafindo Persada.

Khan, W., \& Iqbal, M. (2014). Role of Co-Curricular Activities in School Effectiveness. Middle-East Journal of Scientific Research, 21(11), 2169-2176. https://doi.org/DOI: 10.5829/idosi.mejsr.2014.21.11.21841

Kristiawan, M., Safitri, D., \& Lestari, L. (2017). Manajemen Pendidikan. Yogyakarta: Deepublish. 
Langa, C. (2014). Rewards and Punishments Role in Teacher-Student Relationship from the Mentor's Perspective. Acta Didactica Napocensia, 7(4), 7-12.

Lankshear, C. (2004). A handbook for teacher research: From design to implementation. n.p.: Maidenhead Open University Press.

Leithwood, K., \& Beatty, B. (2007). Leading With Teacher Emotions in Mind. California: Corwin Press.

Macdonald, I., Dixon, C., \& Tiplady, T. (2019). Improving Schools Using Systems Leadership: Turning Intention into Reality. London - New York: Routledge.

Manan, M. M. B. (2014). Leadership Characteristics of Excellent Headmaster. Journal of Education and Practice, 5(23), 120-123.

Marquis, B. L., \& Huston, C. J. (2009). Leadership Roles and Management Functions in Nursing: Theory and Application. Phiuladelphia: Lippincott Williams \& Wilkins.

Millman, J., \& Darling-Hammond, L. (1991). The New Handbook of Teacher Evaluation: Assessing Elementary and Secondary School Teachers. California: Corwin Press.

Moore, C. M. (2012). The Role of School Environment in Teacher Dissatisfaction Among U.S. Public School Teachers. SAGE Open, 2(1), 2158244012438888. https://doi.org/10.1177/2158244012438888

Mosiori, E. M., \& Thinguri, R. W. (2015). A Critical Analysis of the School Headteachers' Capacity in Provision of Quality Education in Primary Schools in Kenya. International Journal of Education and Research, 3(7).

Newby, P. (2013). Research Methods for Education. Hoboken: Taylor and Francis.

Odden, A. (2009). 10 Strategies for Doubling Student Performance. California: Corwin Press.

Oletić, A., \& llić, N. (2014). Intrinsic and Extrinsic Motivation for Learning English as a Foreign Language. ELTA Journal, 2(2), 23-38.

Palanithurai, G. (2011). Globalization and Rural Development. New Delhi: Concept Publishing Company.

Parsons, J., \& Taylor, L. (2011). Improving Student Engagement. Current Issues in Education, 14(1), $1-33$.

Potter, C. C., \& Brittain, C. R. (2009). Child Welfare Supervision: A Practical Guide for Supervisors, Managers, and Administrators. Oxford: Oxford University Press.

Remington, K. (2016). Leading Complex Projects. London - New York: Routledge.

Robertson, M., Corbin, L., Tranter, K., \& Bartlett, F. (2010). The Ethics Project in Legal Education. New York - London: Routledge.

Sansone, C., \& Harackiewicz, J. M. (2000). Intrinsic and Extrinsic Motivation: The Search for Optimal Motivation and Performance. London-California: Academic Press.

Secretariat, C. (2002). Educational Planning and Management in Small States: Concepts and Experiences (G. Baldacchino \& C. J. Farrugia, Eds.). London: Commonwealth Secretariat. 
Shepherd, T. L., \& Linn, D. (2014). Behavior and Classroom Management in the Multicultural Classroom: Proactive, Active, and Reactive Strategies. Washington DC: SAGE Publications.

Simmons, C., \& Hawkins, C. (2009). Teaching ICT. Washington DC: SAGE.

Skager, R. (2014). Organizing Schools to Encourage Self-Direction in Learners. Hamburg: Pergamon.

UNICEF. (2009). Child Friendly Schools Manual. New York: UNICEF.

Visscher, A. J. (2013). Managing Schools Towards High Performance. New York: Routledge.

Wendel, F. C., Hoke, F. A., \& Joekel, R. (1996). Outstanding School Administrators: Their Keys to Success. London: Greenwood Publishing Group.

Wragg, C. M., Haynes, G. S., \& Chamberlin, R. P. (2012). Performance Pay for Teachers. New York - London: Routledge. 